\title{
Individualisation of Education in Terms of E-learning: Experience and Prospects
}

\author{
Iuliia V. Vainshtein*, Victoria A. Shershneva, \\ Roman V. Esin and Mikhail V. Noskov \\ Siberian Federal University \\ 79 Svobodny, Krasnoyarsk, 660041, Russia
}

Received 15.07.2019, received in revised form 28.08.2019, accepted 09.09.2019

The problem of individualisation in education in terms of e-learning remains relevant despite a lot of research done in the area. The present article is intended to review existing education practice individualisation in e-learning and to determine the prospects of development of adaptive e-learning courses that provide the studentwith an individualeducational environment content which focuses on the individual characteristics of students. The authors arrive at the conclusion that building an individual educational trajectory in the adaptive e-learning course has a significant advantage in organising education in the electronic environment for both the student and the teacher. The main feature of these courses becomes the selection of educational content that best matches the individual abilities, needs and needs of the student in an electronic environment. The results of the research are universally applicable and can serve as a basis for organising adaptive web-based teaching not only for mathematics, but also for other disciplines in institutions of secondary, higher and further education.

Keywords: individualization, e-learning, electronic environment, individual educational trajectory, adaptive e-learning courses.

The reported study was funded by RFBR according to the research project No. 18-013-00654.

Research area: pedagogy.

Citation: Vainshtein, Iu.V, Shershneva, V.A., Esin, R.V., Noskov, M.V. (2019). Individualisation of education in terms of e-learning: experience and prospects. J. Sib. Fed. Univ. Humanit. soc. sci., 12(9), 1753-1770. DOI: 10.17516/1997-1370-0481.

\section{Introduction}

Today individualised instruction becomes one of the main directions in modernisation of education. The development of information and communication technologies allows us to talk about individualisation of learning in the electronic

(C) Siberian Federal University. All rights reserved

* Corresponding author E-mail address: YWeinstein@sfu-kras.ru ORCID: 0000-0002-8370-7970

This work is licensed under a Creative Commons Attribution-NonCommercial 4.0 International License (CC BY-NC 4.0). 
environment. The concept of individual training in education has been used for a long time, but progress in the field of ICT allows to take a fresh look at the individualisation of learning by solving the problem between front-end training and the individual characteristics of the student. The current level of ICT makes it possible to provide individualisation for each student. We should point out that personalisation in e-learning is a global trend in modern education. The goal achievement is directly related to the individualisation of educational process, it is quite feasible in the training of students according to individual educational trajectories (IET).

Thus, the rapid development of information and communication technologies and the turn of modernisation of education to tracking the individual characteristics of students allow us to speak about the need to develop new approaches in education that are able to provide individualisation of the educational process in e-learning. One of such approaches is the development and application of adaptive e-learning courses that provide the student with an individual educational environment, theoretical and practical background which focuses on the individual characteristics of students.

It should be noted, however, that the implementation of web-based teaching is a challenging task in pedagogical and technical aspects. In particular, it is caused by the fact that the methodology for e-learning still has not been well developed. In addition, actual participation of the teacher in the e-learning process, unlike the traditional educational process, is not required. We suppose that the role of the teacher can be fulfilled by an adaptive e-learning course.

Taking as a basis the definition of the 'electronic learning resource', which has been given in the Russian Federation National Standard, we understand the adaptive e-learning course (AELC) of a discipline as a learning resource presented in an electronic digital form which includes a structure and content area and provides for the possibility of adaptation depending on student's individual characteristics. The use of adaptive e-learning courses in the educational process allows to individualise the learning process and to increase its effectiveness.

\section{Theoretical framework}

The idea of individualisation in education is not new. The need for an individual approach in education was first mentioned in the works of Jan Amos Komenskii (15921670). In his work The Great Didactics he identified several types of learners, taking into account their individual characteristics: "students with a keen mind seeking for knowledge and who go up to the bit", "there are students with a sharp mind, but slow, 
albeit obedient", "there are students with a sharp mind, eager for knowledge, but hotspur and stubborn", "there are obedient and inquisitive students in teaching, but slow and sluggish" (Komenskii, 1982), as well as two groups of hopeless students, who it is difficult to work with. For some groups J. A. Komenskii provides recommendations on the necessary pedagogical influence. For a long time, individualisation of learning was understood only as taking into account individual age, sex, ethnic and other characteristics of development.

The development of the individualisation of education in the Soviet period experienced great difficulties. It was caused by the ideological denial of the individuality in favour of sociocentric directions. Nevertheless, the elements of individualisation can be seen in the differentiation of learning according to a future profession, which implies training in a specialised vocational school or according to cognitive interests, which implies training in specialised classes with in-depth study of individual subjects. Differentiation of students according to their abilities was considered by Soviet pedagogy as "anti-scientific and anti-humanist system, entailing serious negative consequences of pedagogical and social nature", emphasising the inequality (Danilov et al., 1975). Individualism was opposed to collectivism in all spheres of life: educational, professional and public.

The pedagogy of the Soviet period, the concept of individualisation was still perceived as taking into account individual characteristics in terms of collective learning. In the work High School Didactics (Danilov et al., 1975), the principle of the collective nature of learning and taking into account the individual characteristics of students are underlined. This principle is expressed in the need "to educate the class as an educational team, to create conditions for the active, organised work of all students and at the same time to approach each student individually in order to successfully learn and promote the development of positive inclinations".

Educational reforms that took place at the end of the $20^{\text {th }}$ century brought the principle of individualisation of education to the first place with the development of non-traditional teaching methods. The problems of learning individualisation became the subject of research of many scientists. Since the 1990s, elements of individualisation in education have begun to infiltrate school education actively, but have not yet found their development in the system of higher education.

The phenomenon of individualisation in education is ambiguous and is viewed from various points of view. A. A. Kirsanov considers individualisation of learning as "a system of educational and didactic means corresponding to the activity cycles and 
real cognitive abilities of the class, individual students, groups of students, allowing the student to ensure learning activities at the level of his potential with regard to the objectives of training" (Kirsanov, 1980).

According to I. Unt the principle of individualisation is divided into the differentiation of learning and the individualisation of learning. The definition of differentiation of instruction reflects the view of the individualisation of the Soviet period: "Differentiation of education means taking into account the individual characteristics of students in the form when they are divided on the basis of any features for individual learning" (Unt, 1990). In turn, under individualisation of learning I. Unt understands "taking into account the individual characteristics of students in all its forms and methods in the learning process, no matter what kind of features and what extent are taken into account".

I. S. Iakimanskaia considers the principle of individualisation through an individual approach to learning, which she defines as "the main psychological and pedagogical principle according to which the individuality of each student is taken into account in education as a reflection of its features, psychophysiological organisation in its uniqueness" (Iakimanskaia, 1996).

Modern researchers share points of view on the individualisation of scientists of the Soviet period and expand the content of this concept in the context of selfeducation. "Individualisation of learning is the organisation of the educational process, which is aimed at developing the learner's general cognitive abilities through level differentiation of the content, tasks and methods of learning activities taking into account interests, cognitive needs, actual abilities based on immediate development zone of students" (Getman, Petrusevich, 2014).

Foreign researchers (Maslow, 1954; Manz, 1986) consider individualisation as adaptation and development of the respective outer values, knowledge, technology and norms of behaviour in accordance with the individual characteristics of the subject. The importance of individualisation for human development and its activities is based on the problems and theories of motivation and human needs. The main goal of individualisation in education is to maximise the motivation and initiative of students and teachers.

Cheng in his work defines individualisation as a part of a new paradigm of triplet education, which, along with individualisation, includes globalisation and localisation (Cheng, 2006). Globalisation is the creation of a new educational programme, which is based on world-class materials and maximises relevant research in various subject 
areas. The content of these programmes is due to the technological, economic, social, political, cultural and educational globalisation. Localisation is used in the process of implementing global education programme using local resources to solve the problems of local importance and participation of the interested part of the society. Finally, individualisation allows to make a new educational programme flexible and adaptable in terms of goals, content and teaching methods. This approach to individualisation meets the needs of each student, facilitating their self-study and allows you to optimise your own educational potential. In this paradigm, individualisation identifies the student as the centre of the educational system, who is trained on individual trajectories, realises their potential in the process of self-actualisation focuses on self-learning.

As well as the works of foreign researchers, the works of Russian scientists reflect a new perspective on individualisation, the main innovation which becomes the 'individual educational trajectory' (IET) as an integral component of the individual characteristics of training. For example, "individualisation of education is the organisation of educational activities of students based on the construction of an individual educational trajectory taking into account the individual model of the student in accordance with the personality psychological and pedagogical characteristics".

There are concepts in education that have a related content with the notion of an individual educational trajectory: 'individual educational route', 'individual educational programme', 'individual trajectory of development', 'generalised educational route'.

The concept of 'hypothetical learning trajectories' is introduced in various sources by many of researchers (Ivars et al., 2018). It includes three main aspects: the definition of a learning goal, the progressive development of thinking, training in a chosen subject area and consistent implementation of a set of learning tasks. Depending on the characteristics of the student, the learning process involves different levels of learning tasks for a gradual development in the chosen subject area, we note that the basic development of hypothetical learning trajectories obtained in the mathematical field. The reasons for this lie in the ease of constructing training tasks of various levels that contribute to the gradual growth of mathematical competence.

The concept of 'individualised education plan' is also quite common in literature. Initially, this concept was related to the development of a set of goals for children with various disorders, such as mental retardation, hearing impairment, speech and language disorders, special learning difficulties, visual impairments, emotional disorders, orthopaedic disorders, and various medical conditions classified as 'other health disorders'. However, over time, the content of this concept began to include the 
development of an individual development plan, taking into account the characteristics of any student based not only on their health, but also on gender, information perception, cognitive style, etc. (Goepel, 2009). The thematic diversity of the presented research is united by the practice-orientedness and the search for new educational technologies within the framework of the traditional philosophy of education.

\section{Statement of the problem}

The analysis of the experience of Russian and foreign education systems has shown the difficulties of education individualisation. They are connected with the external factors of the public policy and internal differences in the interpretation of the concepts and approaches to individualisation, the construction of individual educational trajectories. These approaches are undergoing significant changes in the conditions of intensive development of e-learning.

However, there is no coherent concept of web-based teaching at the moment. Therefore, the development of an adaptive e-learning system, which would be able to provide for the construction of individual educational trajectories, based on new approaches, is the current challenge for modern education.

\section{Methods}

As a pedagogical basis for creating an adaptive system of web-based teaching we use the poliparadigmal approach which is defined as an open and consistent cluster of approaches to teaching, the integrated use of which has a synergistic effect (Shershneva, 2014; Kytmanov et al., 2016). The competence-based approach takes the leading position in this cluster. The contextual, interdisciplinary, discipline-based and information technology approaches as well as fundamentalisation continue the hierarchy of approaches by their didactic potential.

The system of web-based teaching includes a set of organisational and pedagogical conditions ensuring that a student acquires knowledge and experience, develops the skills, which result in a competence required for their professional activities (Shershneva et al., 2016).

When designing educational content, the strategy of microlearning is used, which consists of structuring the whole course material in small chunks (Buchem, Hamelmann, 2010). We use modern approaches and methods of teaching mathematics in the creation of the adaptive e-learning course of a mathematical discipline in the frame of the proposed adaptive system. Structuring of the AELC learning material is proposed to be performed on the basis of a hierarchical semantic model of the 
educational content which is represented as a concept tree (Shershneva et al., 2018; Vainshtein et al., 2018). The use of the hierarchy of concepts allows visualising the logical structure of the educational content, determining the sequence of studying the material, and exercising control over the results of course mastering.

Moodle open learning management system is chosen to be the software environment for creation of the AELC. This system has gained a widespread use and offers rich functionality, which allows developing e-learning courses and resources, implementing web-based adaptive teaching, adaptive testing mechanisms and techniques, and building individual educational trajectories. The following features of LMS Moodle can be referred to as its advantages: possibility of expanding the system by means of additional modules, transferability of Moodle developed e-resource components to other platforms, which all support its interoperability (Tsibul'skii et al., 2018).

The empirical base of the study is meant to be the learning results and the results of the questionnaire for the first year students majoring in Information Technology at Siberian Federal University who studied Discrete Mathematics with the use of the adaptive e-learning course and without it.

\section{Discussion}

\section{Content analysis of the IET concept}

The article considers the concept of 'an individual educational trajectory' and carries out a content analysis of its content. All approaches to understanding IET are conditionally divided into three groups: first, the IET is treated as a path in education, the second group defines the individual educational trajectory as a form of organisation of educational activities, and the third describes it as a process of educational activities.

One of the first interpretations of this concept can be found in the works of N. N. Surtaeva, who defines the IET as “a certain sequence of all elements of a student's learning activity for reaching their educational goals, corresponding to their abilities, motivation, opportunities, interests. The teacher performs an organising, coordinating and consulting role" (Surtaeva, 1974).

S. I. Osipova, T. V. Solov'eva, share this point of view. They add that the realisation of educational goals is carried out not only within a separate discipline, but also throughout the entire training period (Osipova, Solov'eva, 2013).

A. V. Khutorskoi defines an individual educational trajectory as a personal way of realising the personal potential of each student, where the realisation of personal potential means its definition and development (Khutorskoi, 2005). 
V. G. Erykova proposes a different approach, considering an individual educational trajectory as a manifestation of the student's style of self-education using an individual trajectory: "An individual educational trajectory is a personality-oriented organisation of educational activities based on the requirements of the GEF and curriculum, ensuring gradual mastering of competencies in professional training for a bachelor and contributing to the formation of an individual style of a student's self-education activity, improvement and transition to an individual style of professional activity" (Erykova, 2008).

A number of scholars consider the individual educational trajectory as a process. For example, O. A. Isakova considers that "an individual educational trajectory is an individual process of student's advancement in education on the basis of the implementation of a choice. It assumes pedagogical support at the substantive and organisational levels, taking into account the abilities, educational needs of the student" (Isakova, 2015).

G.M. Kuleshova focuses on the electronic educational environment, considering it the best way to build an individual educational trajectory. She defines IET as "a project, process and integrated result of productive activities built in the information educational environment using telecommunications and tutoring support aimed at mastering knowledge and skills, building core competencies and self-realisation" (Kuleshova, 2013).

In the context of e-learning, an individual educational trajectory can be defined as an organisational structure and an implementation plan for the educational process in an electronic environment. Such a plan is consistent with the individual specifics of the student and provides opportunities for the optimal development of his potential (Clements, Sarama, 2004; Lazarov, 2013,).

After analysing the interpretations of the IET concept, let us highlight the key characteristics that determine an individual educational trajectory:

- tracking of individual characteristics;

- individual educational space;

- self-determination of learning objectives;

- supervision of the teacher;

- application of electronic environment (e-learning).

We shall pay attention to the description of "self-determination of learning objectives" defining an individual educational trajectory. Universities implement curricula in areas of training in accordance with the regulatory framework and federal 
state educational standards that clearly regulate those goals that should be a priority in the implementation of training in the chosen direction.

Analysis of the concept of an 'individual educational trajectory' has shown that such a feature as the use of e-learning has not been considered practical in the considered approaches. At the same time, the use of e-learning and elements of distance technologies has become firmly established in the practice of higher education and provides a wide ICT functionality for building individual educational trajectories and implementing the principle of individualisation.

\section{E-learning}

The works of domestic and foreign authors (M. Rosenberg, T. Anderson, D. Morrison, A. Rossett, V. P. Tikhomirov, N. V. Tikhomirova, etc.) are devoted to the study of e-learning aspects. They all agree that modern education can no longer be imagined without information technology and e-learning, which has become a part of educational practice (Shershneva et al., 2018; Vainshtein et al., 2018; Zykova et al., 2018).

Currently, it is accepted among foreign and domestic researchers to emphasise three main e-learning models, depending on the degree of implementation of independent work in an electronic environment:

- training with web support;

- blended learning;

- distance learning.

In learning with web-support, the electronic environment acts as an addition to the traditional model of education. The electronic environment is used to provide various reference materials, conduct consultations, organise independent work of students, as well as conduct ongoing or intermediate control on the results of mastering the theoretical material of the discipline.

Blended learning is defined as a combination of full-time and distance learning (Fandei, 2011). Among the authors involved in the development of guidelines for the introduction of blended learning, we can single out Veledenskaya S. B., Dorofeeva M. Iu., Titova S. V., Nazarenko A. L., Mokhov M. N., Shershneva V.A., Clark D., Valiathan P., Dziuban C., Picciano T.. Blended learning is a model based on the integration and mutual addition of traditional and e-learning technologies, which involve replacing parts of traditional training sessions with various types of learning interaction in the electronic environment (Veledinskaia, Dorofeeva, 2014). The blended learning model 
is implemented by the "pre-auditorium — classroom — post-auditor work" cycle with interconnection of e-learning and classroom components (Vainshtein et al., 2017).

In distance learning, the educational process is implemented in an electronic environment, because distance learning does not include classroom instruction. All training materials are available online at any time. The teacher communicates with students (lectures, consultations, etc.) in an electronic environment by means of synchronous (chat rooms, webinars, etc.) and asynchronous (email, forums, etc.) elements and resources.

Therefore, as has been already noted, the current vector of modernisation of modern education is individualisation and the transition to student-centred learning. In the world educational system, individualisation of the educational process in the electronic environment is distributed in the conditions of the new educational technologies formation. The development of e-learning and distance learning technologies is designated as a mandatory component of the formation information space of knowledge in accordance with the presidential decree "Strategy for the development of the information society in the Russian Federation for 2017-2030". A promising direction in the field of improving the quality of education is the development and use of electronic educational courses that give the student a personal educational space, taking into account individual characteristics (Tsibul'skii et al., 2018; Taryma et al., 2019). In this context, individual educational trajectories become a key tool for the implementation of this direction in the electronic environment.

The analysis of the main components of the content of the 'individual educational trajectory' concept with the concept of e-learning allows to synthesise the concept of an individual educational trajectory in the electronic environment. An individual educational trajectory is a consistent movement of a student along the elements of an e-learning course based on their individual characteristics in order to achieve learning outcomes in a discipline and develop subject competence with the advice of a teacher.

\section{Construction of adaptive e-learning courses}

In this paper, we propose to outline the following components in the structure of an adaptive e-learning course: a student model, a domain model and a model for adapting educational content to the individual characteristics of students.

In the student model, we include parameters that characterise the subject of the educational process and are intended to automate the educational process in the AELC. 
Depending on the mechanism of use, two groups of model parameters are distinguished. The parameters of the first group of the model can be repeatedly changed in short time intervals in the process of mastering the discipline and serve to control the intensity of the educational process in the AELC. These include the progress of the course (the position of the student in the course structure) and the characteristics of work in the system (the number of views of the course elements, the time spent and the frequency of attending the course).

The parameters of the second group include the current results of the development of discipline materials and the user's preferences in the way of perceiving information based on its perceptual modality. Based on the parameters of this group, the training content of the e-course is selected.

The construction of the domain model is carried out on the basis of the model of reverse pedagogical design. For a set of competencies implemented in the discipline, a glossary of course concepts (domain concepts) is formed.

All concepts of the glossary are organised in the form of a hierarchical structure of the course concepts using E.K. Voishvillo's principle of the logical-epistemological concept analysis (Voishvillo, 1989). The vertices of the resulting tree correspond to the units of educational material, the concepts of the course. The edges represent the relationship between content units of educational material. Depth-first traversal of the hierarchical structure determines the sequence of studying course materials. After that, the vertices of the tree are combined in the form of course terms. A term is understood as a semantically complete set of vertices of the content tree in the source domain, representing the microportion of educational material (Vainshtein et al., 2017). The result is a linear sequence of learning course terms. Breaking up the process of learning terms by weeks allows us to determine the normative rate of learning in an electronic environment. Each term is represented by several editions of presentation. Each edition is different in its presentation, degree of detail and form of presentation material.

The adaptation model of educational content in the AELC is intended for the realisation of individual educational trajectories. The model is peculiar while it can improve the level of mastering the material by studying the terms of educational content in various editions of the presentation. The educational process management model includes rules for the selection of educational content. They allow recommending for the learner an optimal edition of the current term material being studied based on the set of parameters of the student model. 
At the first stage, the AELC provides entrance testing to determine student preferences and assess input knowledge that is necessary for further studying of the discipline. When identifying gaps in the input knowledge, the general level of training is determined by personal provision of necessary teaching, information and reference and other materials. Thus, at this stage individual educational trajectories begin to be built for each student.

Further, the formation of an individual educational trajectory is based on the achieved level of mastering the terms of the discipline and the individual preferences of the student according to the method of perception of the material. During the transition from term to term, systematic quality control of mastering the course material is carried out by using test materials.

In case of unsatisfactory result of the term development, a transition is made to the repeated study of the term in another version of the presentation, as closely as possible with its current parameters. The number of attempts to test the development of terms is fixed, and the last attempt is always considered the resultant. Thus, after each attempt, including effective, the learner is able to improve the current result (the material studied in another version of presentation) or receives a private decision corresponding to their level about moving to the next term in the editorial. If the number of permissible attempts is exceeded and they are all unsatisfactory, the student is offered to consult with the teacher of the discipline. The technical implementation of the learning content adaptation model in LMS Moodle was carried out by imposing restrictions on the course educational elements: tracking the fulfillment of the elements - studying the revisions of the presentation of the learning content by terms and tracking the current level of learning the terms.

An approbation of the results of applying the AELC in the educational process was carried out in the Discrete Mathematics discipline at the Siberian Federal University in Russia. 121 students of the experimental group and 119 students of the control group participated in the experiment. As a result of the final control over the assimilation of the materials of the AELC in Discrete Mathematics, the effectiveness of the experimental group was on average $14 \%$ higher than in the control group.

In addition, to assess the effectiveness of the proposed algorithms, a questionnaire was carried out for the students of the experimental group and demonstrated the positive reaction of the students to the introduction of the AELC in the study of Discrete Mathematics.

Thus, when assessing the adaptability to the level of assimilation of the material, $67.4 \%$ of respondents noted the option "high level of adaptability", $28.3 \%$ considered 
"the level of adaptability to be rather high" and only $4.3 \%$ chose the option "I do not know".

The majority of respondents $(86.1 \%)$ noted an increase in motivation to study the discipline in the AELC conditions, $13.8 \%$ abstained from an answer and the adaptation of the content seemed rather uninteresting only for $1.1 \%$ of respondents; no one spoke for the total lack of interest in the methods of adapting the educational content.

$67 \%$ of students noted that studying the discipline in the AELC provides better understanding of the subject if compared to traditional teaching, $15 \%$ noted the importance of the proposed approach and $18 \%$ found it difficult to answer this question.

Thus, based on the results of testing the adaptive e-learning course on the Discrete Mathematics discipline, it can be concluded that the organisation of training in the AELC has ensured the formation of a holistic attitude to the discipline, increased motivation to study it and showed the efficiency of using the AELC to ensure the individualisation of training in e-learning environment.

\section{Conclusion}

This article describes a unique structure of the adaptive system of web-based teaching. The scientific novelty of the study consists in structuring the educational content as a hierarchy of terms, original methods and algorithms of adapting learning material, and the learning outcomes assessment model, which provides for the assessment of the level of the subject competence development. The proposed approach to building the educational content model is based on the integration and development of the methods of logical and epistemogical concept analysis with graph theory methods.

Currently, within the framework of the proposed system several adaptive e-learning courses of various disciplines have been developed and successfully implemented at Siberian Federal University.

A number of advantages were revealed for both teachers and students during the implementation of the adaptive e-learning course into the educational process. Namely, the use of the AELC enables the student to build an individual educational trajectory, to form a personal space of educational materials which correspond to their individual characteristics, to organise a flexible learning schedule with constant self-monitoring of learning results, and to improve the quality of the acquired knowledge and skills. A questionnaire among students showed that the AELC use contributed to the cohesive comprehension of the discipline, increased motivation for studying the course and minimised psycho-emotional stress. 
Basing on the studying experience with the AELC, students mentioned the following positive factors: an opportunity of studying the material delivered in a user-friendly form; boosting the efficiency of classroom work caused by the fact that students attend classes being familiar with the theoretical material; an opportunity to practise at any convenient time and at the individual pace. Alongside with that, some students admitted having had difficulties managing their own learning.

The AELC implementation has made it possible for teachers to reduce the volume of broadcast educational material and routine processing of learning results. Although the AELC development is rather labour- and time-consuming, its use in the educational process has led to the reduction in the classroom workload of teachers and the release of the hours that can be used for their professional growth.

Results of approbation allow us to make a conclusion that the considered system is universally applicable and can serve as a basis for organising adaptive web-based teaching not only for Mathematics but also for other disciplines in institutions of secondary, higher and further education.

The introduction of adaptive e-learning courses into the educational process has a good potential for organising individual learning, as the AELCs allow organising student individual work, learning theoretical material.

Materials of this study are of interest for both teachers who develop electronic educational resources and managers of educational institutions interested in implementing such resources in the educational process. We see further development of adaptive web-based teaching in designing and building models of learning management, which provides an intensification of educational processes in the electronic environment in various forms of e-learning and distance learning technologies (blended learning, learning with web support, learning in mass open online courses, etc.). The proposed approach can also become the core of a learning management model that provides a multi-criteria selection of educational content that best matches the individual abilities and needs of the student in an electronic environment.

\section{References}

Buchem, I., Hamelmann, H. (2010). Microlearning: A Strategy for Ongoing Professional Development. In eLearning Papers, 21(7), 1-15.

Cheng, Y.C. (2006). New paradigm for re-engineering education: Globalization, localization and individualization. Springer Science \& Business Media, 504 p. 
Clements, D.H., Sarama, J. (2004). Learning trajectories in mathematics education. In Mathematical thinking and learning, 6(2), 81-89.

Danilov, M.A., Skatkin, M.N., Lerner, I.IA. (1975). Didaktika srednei shkoly. Nekotorye problemy sovremennoi didaktiki [Didactic high school. Some problems of modern didactics]. Moscow, Prosveshchenie, 303 p.

Erykova, V.G. (2008). Formirovanie individual'noi obrazovatel'noi traektorii podgotovki bakalavrov informatiki [Formation of an individual educational trajectory of training bachelors of computer science]. Moscow, Rossiiskii gosudarstvennyi sotsial'nyi universitet, $25 \mathrm{p}$.

Fandei, V.A.(2011). Smeshannoe obuchenie: sovremennoe sostoianie iklassifikatsiia modelei smeshannogo obucheniia [Blended learning: current state and classification of blended learning models]. In Informatizatsiia obrazovaniia i nauki [Informatisation of education and science], 12, 115-125.

Getman, N.A., Petrusevich, A.A. (2014). Organizatsionno-pedagogicheskie usloviia individualizatsii obucheniia studentov v vysshei shkole [Organisational and pedagogical conditions for the individualisation of teaching students in higher education]. In Omskii nauchnyi vestnik [Omsk Scientific Bulletin], 3(129), 125-128.

Goepel, J. (2009). Constructing the Individual Education Plan: confusion or collaboration. In Support for learning, 24(3), 126-132.

Iakimanskaia, I.S. (1996). Lichnostno-orientirovannoe obuchenie v sovremennoi shkole [Student-centered education in modern school]. Moscow, Sentiabr', 96 p.

Isakova, O.A. (2015). Individual'naia obrazovatel'naia traektoriia shkol'nika kak sredstvo dostizheniia lichnostnykh rezul'tatov [Individual educational trajectory of the student as a means of achieving personal results]. St. Petersburg, Institut pedagogicheskogo obrazovaniia i obrazovaniia vzroslykh RAO, 23 p.

Ivars, P., Fernandez-Verdu, C., Llinares, S., Choy, B.H. (2018). Enhancing Noticing: Using a Hypothetical Learning Trajectory to Improve Pre-service Primary Teachers' Professional Discourse. In EURASIA Journal of Mathematics, Science and Technology Education, 14(11), 1-16.

Khutorskoi, A.V. (2005). Metodika lichnostno-orientirovannogo obucheniia. Kak obuchat' vsekh po-raznomu? [Methods of student-centered learning. How to train everyone in different ways?]. Moscow, Vlados-Press, 383 p.

Kirsanov, A.A. (1980). Individualizatsiia uchebnoi deiatel'nosti shkol'nikov [Individualisation of educational activities of schoolchildren]. Kazan, Tatarstanskoe knizhnoe izdatel'stvo, 207 p. 
Komenskii, Ia.A. (1982). Izbrannye pedagogicheskie sochineniia [Selected pedagogical works]. Moscow, Znanie, 576 p.

Kuleshova, G.M. (2013). Model' organizatsii individual'noi obrazovatel'noi traektorii uchenika v distantsionnom evristicheskom obuchenii [Model of organization of individual educational trajectory of a student in distance heuristic training]. In Izvestiia Rossiiskogo gosudarstvennogo pedagogicheskogo universiteta im. A.I. Gertsena [Proceedings of the Russian State Pedagogical University], 63(2), 1-12.

Kytmanov, A.A., Noskov, M.V., Safonov, K.V., Savelyeva, M.V., Shershneva, V.A. (2016). Competency-based Learning in Higher Mathematics Education as a Cluster of Efficient Approaches. In Bolema: Mathematics Education Bulletin, 30(56), 1113-1126. DOI: 10.1590/1980-4415v30n56a14.

Lazarov, B. (2013). Application of some cybernetic models in building individual educational trajectory. In Information Models and Analyse, 2(1), 90-99.

Manz, C.C. (1986). Self-leadership: Toward an expanded theory of self-influence processes in organizations. In Academy of Management review, 11(3), 585-600.

Maslow, A.H. (1954). Motivation and personality. New York, Harper \& Brothers, $411 \mathrm{p}$.

Osipova, S.I., Solov'eva, T.V. (2013). Proektirovanie studentom individual'noi obrazovatel'noi traektorii v usloviiakh informatizatsii obrazovaniia [Designing by the student of an individual educational trajectory in the conditions of informatization of education]. Moscow, Krasnoyarsk, INFRA-M, Sibirskii federal'nyi universitet, 140 p.

Shershneva, V., Vainshtein, Iu., Kochetkova, T. (2018). Adaptive system of webbased teaching, In Program Systems: Theory and Applications, 9(39), 179-197. DOI: 10.25209/2079-3316-2018-9-4-179-197.

Shershneva, V.A. (2014). Formirovanie matematicheskoi kompetentnosti studentov inzhenernogo vuza [Development of mathematical competence for engineering students]. In Pedagogika [Pedagogy], 5, 62-70.

Shershneva, V.A., Shkerina, L.V., Sidorov, V.N., Sidorova. T.V., Safonov, K.V. (2016). Contemporary didactics in higher education in Russia. In European Journal of Contemporary Education, 17(3), 357-367.

Surtaeva, N.N. (1974). Netraditsionnye pedagogicheskie tekhnologii: Paratsentricheskaia tekhnologiia [Nontraditional pedagogical technologies: Paracentric technology]. Moscow, Omsk, 22 p.

Taryma, A.K., Shershneva, V.A., Vainshtein, Iu.V. (2019). Peculiar features of learning process organization in electronic environment providing the development of 
professional ICT competence for future teachers of the Tuva Republic. In Perspectives of Science \& Education, 40, 48-62.

Tsibul'skii, G.M., Vainshtein, Iu.V., Esin, R.V. (2018). Razrabotka adaptivnykh elektronnykh obuchaiushchikh kursov v srede LMS Moodle [Development of adaptive e-learning courses in the LMS Moodle]. Krasnoyarsk, Siberian Federal University, Sibirskii federal'nyi universitet, $168 \mathrm{p}$.

Unt, I. (1990). Individualizatsiia i differentsiatsiia obucheniia [Individualisation and differentiation of learning]. Moscow, Pedagogika, 192 p.

Vainshtein, Iu.V., Esin, R.V., Tsibul'skii, G.M. (2017). Adaptivnaia model' postroeniia individual'nykh obrazovatel'nykh traektorii pri realizatsii smeshannogo obucheniia [Adaptive model of developing individual educational trajectories for blended learning]. In Education and Informatics [Informatika i obrazovanie], 2 (281), 83-86.

Vainshtein, Iu.V., Shershneva, V.A., Vainshtein, V.I., Kosmidis, I.F. (2018). Kompetentnostnyi podkhod i sredstva otsenki kachestva podgotovki studentov $\mathrm{v}$ adaptivnykh elektronnykh obuchaiushchikh kursakh [Competency-based approach and tools for student training quality evaluation in adaptive e-learning courses]. In Sovremennye issledovaniia sotsial'nykh problem (elektronnyi nauchnyi zhurnal) [Modern studies of social problems (electronic scientific journal)], 9(5), 19-30.

Veledinskaia, S.B., Dorofeeva, M.I. (2014). Smeshannoe obuchenie: sekrety effektivnosti [Blended learning: the secrets of efficiency]. In Vysshee obrazovanie segodnia [Higher education today], 8, 8-13.

Voishvillo, E.K. (1989). Poniatie kak forma myshleniia: logiko-gnoseologicheskii analiz [Concept as a form of thinking: logical-and-gnoseological analysis]. Moscow, MGU, $240 \mathrm{p}$.

Zykova, T., Shershneva, V.A., Vainshtein, Iu.V., Danilenko, A.S., Kytmanov, A. (2018). E-learning courses in mathematics in higher education. In Perspectives of Science \& Education, 34(5), 58-65. 


\title{
Индивидуализация образования \\ в условиях электронного обучения: \\ опыт и перспективы
}

\author{
Ю. В. Вайнштейн, В.А. Шершнева, \\ Р. В. Есин, М.В. Носков \\ Сибирский федеральный университет \\ Россия, 660041, Красноярск, пр. Свободньй, 79
}

\begin{abstract}
Проблема индивидуализации образования в условиях применения электронного обучения остается актуальной, несмотря на множество исследований, проведенных в этой области. Цель данной статьи - рассмотреть существующие практики индивидуализачии образования в условиях электронного обучения и определить перспективность разработки адаптивных электронных обучающих курсов, предоставляющих студенту индивидуальную образовательную среду, контент которой ориентирован на личностные характеристики обучающихся. Авторы статьи приходят к заключению, что построение индивидуальной образовательной траектории в адаптивном электронном обучающем курсе обладает существенным преимуществом при организации обучения в электронной среде как для студента, так и для преподавателя, главной задачей которого становится подбор образовательного контента, максимально соответствующего способностям, запросам и потребностям обучающегося в электронной среде. Результаты исследования являются универсальными и могут служить основой для организации адаптивного обучения в электронной среде не только по математическим, но и по другим дисциплинам образовательных программ различных направлений подготовки как в школах, так и в высших учебных заведениях.
\end{abstract}

Ключевые слова: индивидуализация, электронное обучение, электронная среда, индивидуальная образовательная траектория, адаптивные электронные обучающие курсы.

Исследование выполнено при финансовой поддержке РФФИ в рамках научного проекта № 18-013-00654 - «Технология разработки адаптивных обучающих систем, обеспечивающая персонализаџию обучения в электронной среде».

Научная специальность: 13.00.00 - педагогические науки. 